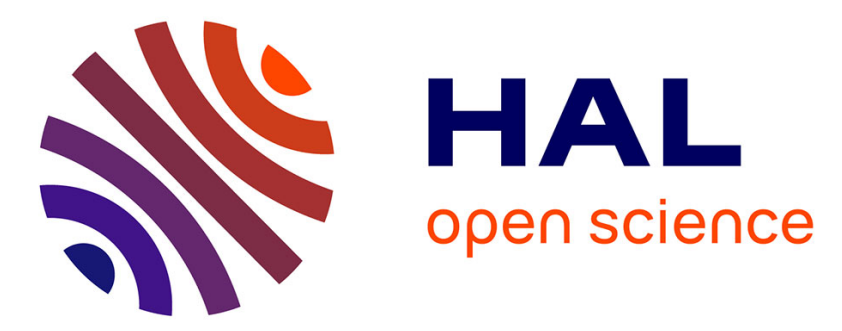

\title{
Environmental impact of early Basque mining and smelting recorded in a high ash minerogenic peat deposit
}

Fabrice Monna, Didier Galop, Laurent Carozza, Magali Tual, Argitxu Beyrie, Fabrice Marembert, Carmela Chateau, Janus Dominik, F. E. Grousset

\section{- To cite this version:}

Fabrice Monna, Didier Galop, Laurent Carozza, Magali Tual, Argitxu Beyrie, et al.. Environmental impact of early Basque mining and smelting recorded in a high ash minerogenic peat deposit. Science of the Total Environment, 2004, pp. 197-214. halshs-00759153

\section{HAL Id: halshs-00759153 \\ https://shs.hal.science/halshs-00759153}

Submitted on 20 Mar 2014

HAL is a multi-disciplinary open access archive for the deposit and dissemination of scientific research documents, whether they are published or not. The documents may come from teaching and research institutions in France or abroad, or from public or private research centers.
L'archive ouverte pluridisciplinaire HAL, est destinée au dépôt et à la diffusion de documents scientifiques de niveau recherche, publiés ou non, émanant des établissements d'enseignement et de recherche français ou étrangers, des laboratoires publics ou privés. 


\title{
Environmental impact of early Basque mining and smelting recorded in a high ash minerogenic peat deposit
}

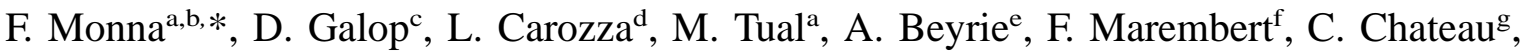 \\ J. Dominik ${ }^{\mathrm{h}}$, F.E. Grousset ${ }^{\mathrm{i}}$ \\ ${ }^{a}$ Laboratoire GéoSol, UMR INRA - Université de Bourgogne A111, CST, 6 bd Gabriel, F-21000 Dijon, France \\ bArchéologies, Cultures et Sociétés. Bourgogne et France Orientale du Néolithique au Moyen Age, \\ UMR 5594 CNRS-Université de Bourgogne, Bat. Gabriel, F-21000 Dijon, France \\ ${ }^{\mathrm{c}}$ Laboratoire de Chrono-Ecologie, UMR 6565 CNRS, UFR des Sciences et Techniques, Université de Besançon, 16 route de Gray, \\ F-25030 Besançon Cedex, France \\ ${ }^{\mathrm{d}}$ INRAP Grand-Est UMR 8555, Centre d'Anthropologie, F-21000 Dijon, France \\ ${ }^{\mathrm{e}} U T A H$ - UMR 5608 CNRS, Maison de la Recherche, Université Toulouse - le Mirail, F-31058 Toulouse Cedex, France \\ ${ }^{\mathrm{f}}$ Centre d'anthropologie, UMR 8555 CNRS, 30 allée Jules Guesde, F-31000 Toulouse, France \\ ${ }^{\mathrm{g}}$ Centre des Sciences de la Terre, 6 bd Gabriel, F-21000 Dijon, France \\ ${ }^{\mathrm{h}}$ Institut F.-A. Forel, Université de Genève, 10 route de Suisse, CH-1290 Versoix, Switzerland \\ iDépartement de Géologie et Océanographie, UMR CNRS 5805 EPOC, Université Bordeaux 1, Avenue des Facultés, \\ F-33405 Talence, France
}

Received 1 June 2003; received in revised form 28 January 2004; accepted 30 January 2004

\begin{abstract}
More than four metres of core, covering almost 5000 years of deposition, were collected in a high ash minerogenic peat deposit located in the High Aldudes valley (Basque country), an area well known for its mineral abundance, exploited from Roman Times at least. Although minerogenic peatlands are not generally considered as the best archives to reconstruct past atmospheric metal deposition history, lead isotopic geochemistry demonstrates the integrity of the $\mathrm{Pb}$ record at least within the three upper meters; that is to say over the last four millennia. $\mathrm{Zn}, \mathrm{Cd}$ and $\mathrm{Cu}$ may have been widely redistributed either by biological cycling, advective groundwater movements, or diffusional processes. Anthropogenic lead input phases are clearly pinpointed by positive shifts in $\mathrm{Pb} / \mathrm{Sc}$ ratios with concomitant sharp drops in ${ }^{206} \mathrm{~Pb} /{ }^{207} \mathrm{~Pb}$ ratios. They are often accompanied by significant declines in tree taxa, interpreted as increasing demand for wood to supply energy for local mining and/or metallurgical operations. Periods of mining and/or smelting activity are identified during Antiquity and Modern Times, and are also confirmed by textual and field evidence. Inputs from the Rio Tinto (Southern Spain), often invoked as a major lead contributor to the European atmosphere during Roman Times, were not detected here. This remote source was probably masked by local inputs. Other mining and/or smelting phases, only suspected by archaeologists, are here identified as early as the Bronze Age. Although the durations of these phases are possibly overestimated because of detrital inputs consequent to the release of lead from polluted soils over a long period of time after major pollutant inputs, the periods at which pollution peaks occur are in good agreement with archaeological knowledge and palaeo-botanical data. The
\end{abstract}

*Corresponding author. Present address: UMR 5594 CNRS-Université de Bourgogne CST, 6 bd Gabriel, F-21000 Dijon, France. Tel.: + 33-3-80-396-360; fax: +33-3-80-396-387.

E-mail address: Fabrice.Monna@u-bourgogne.fr (F. Monna). 
combination of geochemical and palaeo-botanical techniques with field archaeology, therefore provides a powerful tool in studying the interaction of early human societies with their environment, as regards early mining and smelting. (c) 2004 Elsevier B.V. All rights reserved.

Keywords: Pollution; Lead isotopes; Peat deposit; Atmospheric deposition; Mining; Smelting

\section{Introduction}

The oldest French settlement of copper miners and metalworkers (3rd millennium BC) has been recently discovered close to Montpellier-Southern France (Ambert et al., 2002). Such exploitation was probably initiated under the stimulus of populations living in the Alpine arc, themselves influenced by precursor cultures from the Balkans, Hungary, Poland and Germany (Chapman and Tylecote, 1983; Gale et al., 1991). Early metallurgical centres seem also to have existed, probably as far back as the Late Neolithic, in Northern Africa and Southern Spain, although definitive proof is still lacking (Rovira, 1998). This forces us to reconsider the relationships between populations living in Eastern and in South-West Europe from the Late Neolithic to the Bronze Age. The mineral-rich Basque country, with its key geographical position, may have interlinked both these cultures. However, even if remains of local extraction during antiquity are numerous, no proof of earlier mining has yet been found. Prehistoric mining was superficial, focusing on a simple handpicking of minerals, and evidence may have been masked or destroyed by subsequent activities.

However, traces of historical mining or smelting may have been recorded in natural archives. The efficiency of such an environmental approach has been successfully demonstrated at least for lead, at continental scale as well as at local scale, in sediments (Brännvall et al., 1997; Schettler and Romer, 1998; Camarero et al., 1998; Brännvall et al., 1999; Monna et al., 2000a; Renberg et al., 2000, 2001; Ariès, 2001; Eades et al., 2002; Degryse et al., 2003), polar ice (Hong et al., 1994; Rosman et al., 1997), and peatlands (Glooschenko et al., 1986; Van Geel et al., 1989; Kempter et al., 1997; Weiss et al., 1997; Farmer et al., 1997; Kempter and Frenzel, 2000; Shotyk et al., 1998, 2001; Mighall et al., 2002; Martínez-Cortizas et al., 1997, 2002). Concerning peatlands, it is generally accepted that the most appropriate media are ombrotrophic peat bogs because their chemistry and hydrology tend to promote the immobility of metals deposited (Lee and Tallis, 1973; Jones and Hao, 1993; Shotyk, 1996a; Norton et al., 1997; Martínez-Cortizas et al., 1997; Shotyk et al., 1998; MacKenzie et al., 1998a). Evidence of post-depositional lead migrations has already been noticed, at the time scale of the last century, in minerogenic peatlands with ash content less than $10 \%$, making historical interpretation impossible (MacKenzie et al., 1998b). However, at the millennia time scale, coherent lead records have also been reported in marshes featured by high ash content reaching up to $94 \%$ (Alfonso et al., 2001). Other studies performed in mineral-rich peatlands (Espi et al., 1997; Shotyk, 2002), indicate that even predominantly minerogenic sites may properly preserve the record of anthropogenic atmospheric $\mathrm{Pb}$ deposition or, at least, may provide a qualitative surrogate for historical pollution (Shotyk, 1996b, 2002). In all cases, anthropogenic inputs have to dominate over detrital contribution (Weiss et al., 1999), and mineral dissolution of the underlying sediments must not contribute measurably to the lead inventory (Shotyk, 2002). Invaluable information on the sources may be obtained by the measurement of lead isotopic compositions (Brännvall et al., 1997; Shotyk et al., 1998; MacKenzie et al., 1998b; Weiss et al., 1999; Dunlap et al., 1999; Renberg et al., 2000; Alfonso et al., 2001; Ariès, 2001; Weiss et al., 2002; Martínez-Cortizas et al., 2002; Shotyk et al. 2002a,b; Monna et al., 2004).

Regrettably ombrotrophic peat bogs are not available in the High Aldudes Valley, a Basque valley well known for its mineral abundance, so we had to investigate the possible use of geochemical signals archived in high ash minerogenic peatlands to constrain the history of local mining 
and smelting operations. The pollen record has been investigated too. It generally mirrors the influence of climate and anthropogenic pressure, such as cultivation, pastoral activities and forest clearance (Williams, 2000), but signs of deforestation may also be related to energy demands for metal production (Galop and Jalut, 1994; Blanchot et al., 2001), unless they result from agricultural extension. All these new data are confronted to the sparse archaeological knowledge available.

\section{The site and local history}

Palaeozoic Basque mountains and Permo-Triassic cover contain abundant mineral resources, so that exploration was re-launched in the late 1970s (Fig. 1). Most of the ore deposits are found in upper ordovician detrital formations composed of bulky sandstones, alternation of pelites and sandstones, and black pelites. Mined from Roman Times (Galop et al., 2001; Beyrie et al., in press), ores of $\mathrm{Fe}, \mathrm{Cu}, \mathrm{Ag}, \mathrm{Sb}$, and to a lesser extent of $\mathrm{Pb}$ and $\mathrm{Zn}$, consist of sub-concordant piles or secant veins governed by fractures. In the Middle Ages, this district furnished Bayonne with silver for coinage (Gapillou, 1981). Before the French Revolution, annual production reached more than 100 tons of copper, but exploitation then collapsed because of the lack of wood consequent to intense deforestation. In 1793, Spanish troops plundered the village of Banca and destroyed $\mathrm{Cu}$ smelting installations. Marginal exploitation is reported throughout the 19th and 20th centuries. This area yielded more than 20000 tons of metallic copper (it is the richest district in France) and approximately 400 tons of silver.

The district of St. Martin d'Arrossa lies directly on Palaeozoic formations. It mainly consists of pile and vein stockwork of siderite, which can be locally associated with $\mathrm{Cu}$. Also, mined by Romans, it was sporadically worked for iron from the 18th century, and more substantially from the late 19th century to the World War I.

The Quinto Real peat deposit (cf. Fig. 1) is located close to the Spanish border (910 m a.s.l.), almost at the interfluve of the Baztan and Aldudes valleys. It lies on a surface of approximately 1 ha on Palaeozoic terrain. Sphagnum-dominated at the top, it is fed by some temporary streams originating from a small catchment area (Galop et al., 2001). The site is far from any current settlements.

\section{Material and methods}

\subsection{Sampling}

Sampling was carried out using a Russian GIKtype corer ( $8 \mathrm{~cm}$ in diameter) following the conventional two-borehole technique. The samples were wrapped in clean plastic bags in order to prevent external contamination. Sub-sampling for geochemical analysis was performed by cutting 2$\mathrm{cm}$ thick sections at intervals of $4 \mathrm{~cm}$, after removing with a PTFE spatula the outer parts, which could have been in contact with the corer, the tube or the plastic film. A few coarse roots, mostly present at the top, were removed using clean plastic pliers. Samples were transferred to LDPE beakers and slowly dried at $60{ }^{\circ} \mathrm{C}$ for 3 days. They were finely powdered in an automatic agate mortar pre-cleaned with diluted $\mathrm{HCl}$ and MilliQ water, then stored in the dark before further analyses. Sub-sampling for pollen analysis was carried out at $4 \mathrm{~cm}$ intervals in the first metre, and at $8 \mathrm{~cm}$ intervals to the bottom. These latter were kept wet until pollen preparation as described below.

\subsection{Chemical composition}

Lost on ignition (LOI) was performed by heating approximately $1 \mathrm{~g}$ of peat samples to $90{ }^{\circ} \mathrm{C}$, and then by combustion at $450{ }^{\circ} \mathrm{C}$ for $4 \mathrm{~h}$. Total organic carbon (TOC) was also measured twice on half of the samples by Nitrogen Carbon Analyser (NA $1500 \mathrm{~W}-2$ - Carlo Erba) at a precision of 5\%. LOI and TOC were closely correlated (LOI $=1.81 \times$ TOC, $\left.r^{2}>0.99, P<0.01\right)$. Refractory elements such as $\mathrm{Sc}, \mathrm{Th}, \mathrm{Cr}, \mathrm{Rb}$ and $\mathrm{La}$ and REE were measured by instrument neutron activation analysis (INAA) at Actlabs (Ontario, Canada). Accuracy was checked within $\pm 10-15 \%$ on the basis of standards routinely measured and NIST 1547, PACS-1, BCSS-1 added to the set.

For complementary determinations, approximately $500 \mathrm{mg}$ of powdered samples were oxidized 


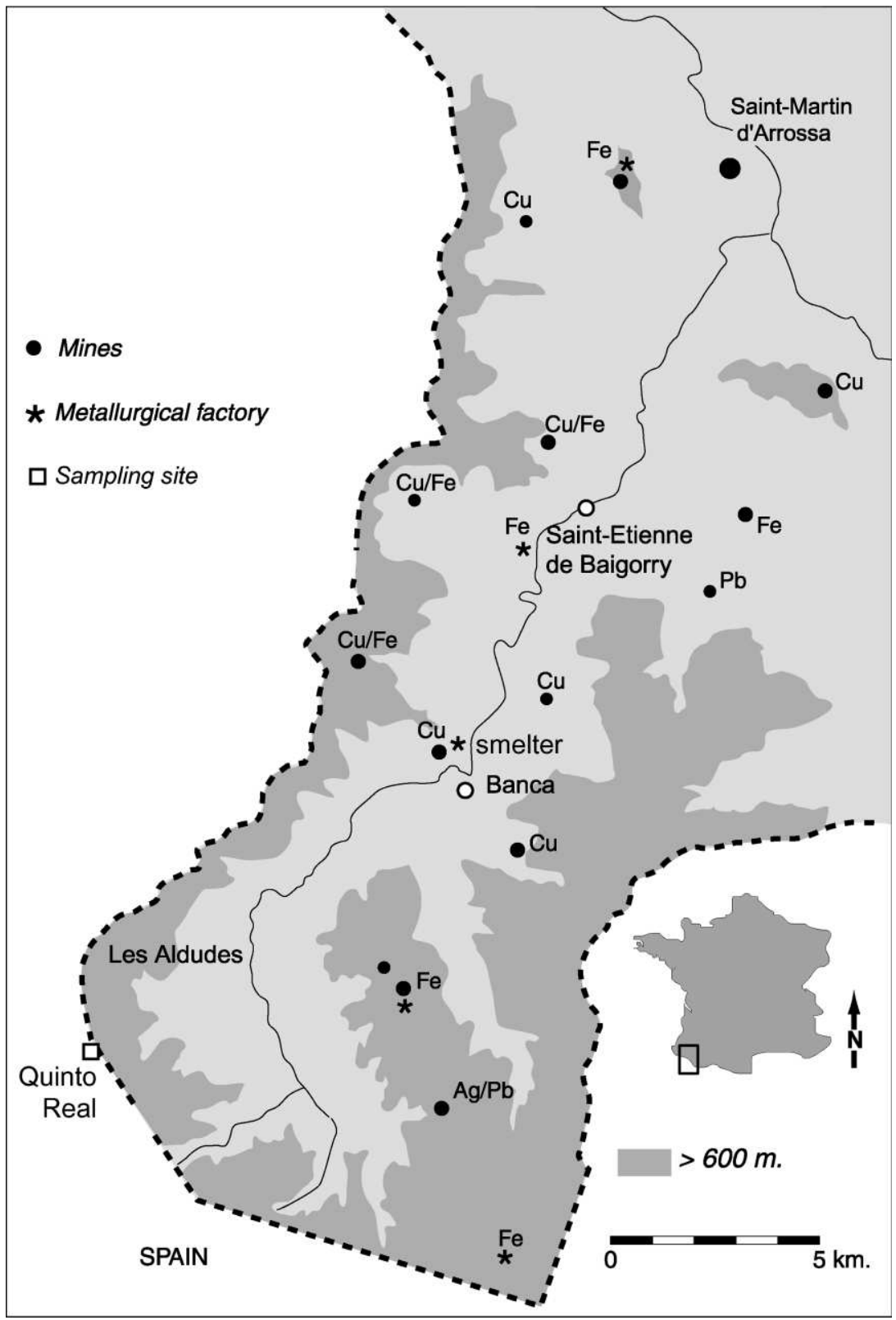

Fig. 1. Map of the Basque country. The ore guides and their nature have been reported.

with $4 \mathrm{ml}$ of Suprapur $\mathrm{H}_{2} \mathrm{O}_{2}$ (Merck-Germany), reacting on hot plate at $40{ }^{\circ} \mathrm{C}$ overnight. Once dried, samples were digested with a mixture of Suprapur and concentrated $\mathrm{HCl}, \mathrm{HNO}_{3}$ and $\mathrm{HF}$ (Merck, Germany) in closed PTX vessels under Milestone-ETHOS microwave assistance (Monna et al., 2000a). One blank and one reference material standard (RMS), among NIST 1547, JSD 1 and JSD 2, were added to each set.

A one-third aliquot of solution was measured at the F.-A. Forel Institute by HP 4500 inductively coupled plasma-mass spectrometer (ICP-MS) for 
$\mathrm{Cu}, \mathrm{Zn}, \mathrm{Cd}$ and $\mathrm{Pb}$ concentration determination using both external and internal $(\mathrm{Re}, \mathrm{Rh})$ calibrations. The whole procedure was performed in a clean room (US class 1000-10 000). Blanks were found negligible for all elements compared to the amount contained in the samples. $\mathrm{Pb}, \mathrm{Cd}$ and $\mathrm{Cu}$ concentrations were in good agreement with the certified values of RMSs (within $\pm 10 \%$ for lead and copper, and at worst approximately $\pm 15-$ $20 \%$ for $\mathrm{Cd}$ and $\mathrm{Zn}$ ). Lead from the two-thirds aliquot was pre-concentrated on ionic resin AG1X4 (Biorad) and measured for isotopic abundance by HP 4500 ICP-MS (Monna et al., 1998, 2000b). Precisions of ${ }^{206} \mathrm{~Pb} /{ }^{207} \mathrm{~Pb}$ and ${ }^{208} \mathrm{~Pb} /{ }^{206} \mathrm{~Pb}$ ratios were approximately $0.27 \%$ and $0.31 \%$, respectively. Seven samples were duplicated with the Perkin Elmer 6100 ICP-MS at the University of Neuchâtel. In all cases, the $95 \%$ confidence intervals overlapped. Pristine fragments of artefacts were obtained by scratching with a stainless steel tool. They were washed with a mixture of diluted Suprapur $\mathrm{HCl}$ and $\mathrm{HNO}_{3}$ to remove any remains of corrosion or pollution. The fragments were dissolved and lead isotopes were measured following the procedure described above.

\subsection{Radiocarbon dating}

Three peat samples were dated using ${ }^{14} \mathrm{C}$-beta counting at the Centre des Sciences de la TerreUniversity of Lyon (Table 1, Fig. 2), and two others by AMS at Beta Analytic Inc laboratory, Miami. All ${ }^{14} \mathrm{C}$-dates were calibrated using Calib 4.1.3 software (Stuiver et al., 1998).

\subsection{Pollen determination}

Briefly, pollen preparation consists in treatments with $10 \% \mathrm{HCl}, 10 \% \mathrm{KOH}, \mathrm{HF}$, acetolysis and

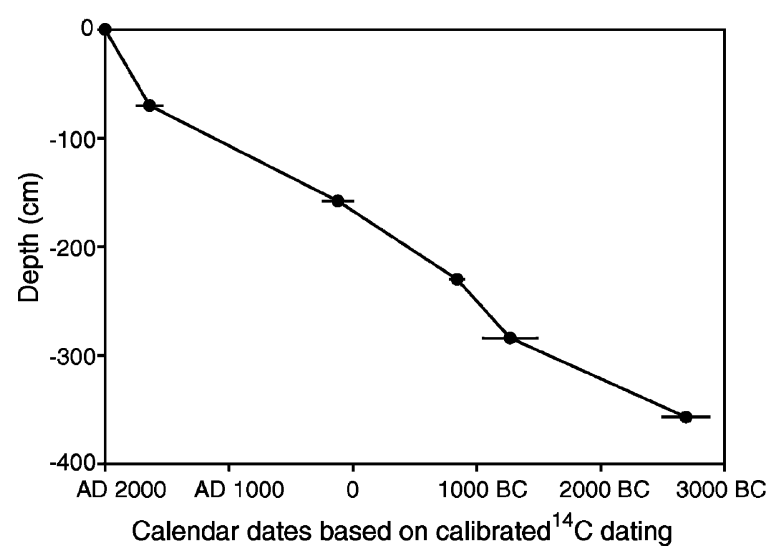

Fig. 2. Depth plotted against calibrated radiocarbon calendar dates at Quinto Real, Basque country, France.

final mounting in glycerine. More than 500 terrestrial pollen grains, defined according to Reille (1992) and Moore et al. (1986) were counted in each sample. Cyperaceae and spores were systematically excluded from the pollen sum, as was Alnus; its over-representation may mask the dynamics of other taxa (Wiltshire and Edwards, 1993). Pollen spectra have been given elsewhere (Galop et al., 2001). They will be used here only for discussion.

\section{Results}

\subsection{Organic matter and lithophilic elements}

The LOI profile (Table 2, Fig. 3) exhibits wide variations, from $7 \%$ in the layer richest in sand (321-cm depth) to $85 \%$ at the top. The first 300 $\mathrm{cm}$ are the most organic (avg: 60\%); although two sections, at 63-86 and $134-157-\mathrm{cm}$ depth, are more mineral. The uppermost $300 \mathrm{~cm}$ can be

Table 1

Age-depth relationship for the Quinto Real core. The data are calibrated to calendar dates AD or BC

\begin{tabular}{lccl}
\hline Laboratory no. & Depth $(\mathrm{cm})$ & Uncalibrated date & Calibrated date, and uncertainties $(2 \sigma)$ \\
\hline Beta-156998 & $69-71$ & $290 \pm 40$ & $1486(1640) 1664 \mathrm{cal} \mathrm{AD}$ \\
Ly-10587 & $157-159$ & $1895 \pm 50$ & $3(88,100,125) 240 \mathrm{cal} \mathrm{AD}$ \\
Ly-10588 & $229-231.5$ & $2645 \pm 45$ & $896(804) 787 \mathrm{cal} \mathrm{BC}$ \\
Ly-10589 & $283-285$ & $3045 \pm 70$ & $1485(1368,1362,1315) 1051 \mathrm{cal} \mathrm{BC}$ \\
Beta-156997 & 357 & $4120 \pm 40$ & $2876(2662,2646,2625) 2501 \mathrm{cal} \mathrm{BC}$ \\
\hline
\end{tabular}


Table 2

Lost on ignition (LOI), Cu, Zn, Cd, $\mathrm{Pb}, \mathrm{Sc}$ contents and ${ }^{206} \mathrm{~Pb} /{ }^{207} \mathrm{~Pb}$ and ${ }^{208} \mathrm{~Pb} /{ }^{206} \mathrm{~Pb}$ ratios. The errors for isotopic ratios are given at $95 \%$ confidence level. See Section 3 paragraph for errors in concentration measurements

\begin{tabular}{|c|c|c|c|c|c|c|c|c|c|c|c|}
\hline Name & $\begin{array}{l}\text { Depth } \\
(\mathrm{cm})\end{array}$ & LOI\% & $\begin{array}{l}\mathrm{Cu} \\
\mu \mathrm{g} \mathrm{g}^{-1}\end{array}$ & $\begin{array}{l}\mathrm{Zn} \\
\mu \mathrm{g} \mathrm{g}^{-1}\end{array}$ & $\begin{array}{l}\mathrm{Cd} \\
\mu \mathrm{g} \mathrm{g}^{-1}\end{array}$ & $\begin{array}{l}\mathrm{Pb} \\
\mu \mathrm{g} \mathrm{g}^{-1}\end{array}$ & $\begin{array}{l}\text { Sc } \\
\mu g_{g}^{-1}\end{array}$ & $\begin{array}{l}{ }^{206} \mathrm{~Pb} / \\
{ }^{207} \mathrm{~Pb}\end{array}$ & \pm & $\begin{array}{l}{ }^{208} \mathrm{~Pb} / \\
{ }^{206} \mathrm{~Pb}\end{array}$ & \pm \\
\hline R 007 & -7 & nd & 3.9 & 47.5 & 0.34 & 75.1 & nd & 1.159 & 0.003 & 2.103 & 0.006 \\
\hline R 012 & -12 & nd & 17.9 & 133.3 & 1.35 & 267.6 & nd & 1.160 & 0.003 & 2.100 & 0.006 \\
\hline R 016 & -16 & nd & 5.5 & 102.7 & 1.19 & 765.0 & 0.5 & 1.165 & 0.004 & 2.105 & 0.006 \\
\hline R 020 & -20 & nd & 4.4 & 39.8 & 1.03 & 109.2 & 0.8 & 1.163 & 0.009 & 2.105 & 0.006 \\
\hline R 028 & -28 & 85.2 & 10.4 & 30.0 & 1.02 & 140.7 & 2.3 & 1.172 & 0.004 & 2.095 & 0.006 \\
\hline R 036 & -36 & 59.7 & 10.5 & 16.3 & 0.34 & 19.2 & 6.5 & 1.179 & 0.003 & 2.086 & 0.008 \\
\hline R 045 & -45 & 54.1 & 13.4 & 19.8 & 0.32 & 5.4 & 6.5 & 1.183 & 0.002 & 2.102 & 0.005 \\
\hline R 055 & -55 & 50.9 & 15.3 & 16.7 & 0.20 & 7.9 & 9.7 & 1.194 & 0.003 & 2.088 & 0.006 \\
\hline R 063 & -63 & 42.9 & 7.9 & 7.9 & 0.31 & 8.8 & 10.7 & 1.197 & 0.002 & 2.105 & 0.006 \\
\hline R 071 & -71 & 37.8 & 8.9 & 14.6 & 0.23 & 14.1 & 13.1 & 1.191 & 0.008 & 2.107 & 0.007 \\
\hline R 078 & -78 & nd & 8.1 & 12.6 & nd & 10.3 & 12.1 & nd & nd & nd & nd \\
\hline R 086 & -86 & 41.6 & 12.7 & 16.0 & 0.21 & 19.2 & 13.0 & 1.190 & 0.003 & 2.099 & 0.005 \\
\hline R 095 & -95 & 55.6 & 11.2 & 21.6 & 0.23 & 9.2 & 9.1 & 1.190 & 0.003 & 2.105 & 0.005 \\
\hline R 101 & -101 & 57.0 & 14.3 & 16.2 & 0.11 & 13.8 & 8.9 & 1.183 & 0.001 & 2.101 & 0.008 \\
\hline R 113 & -113 & 62.6 & 12.7 & 10.2 & 0.19 & 10.2 & 7.4 & 1.188 & 0.004 & 2.091 & 0.007 \\
\hline R 117 & -117 & 59.5 & 13.6 & 16.0 & nd & 13.3 & 7.7 & nd & nd & nd & nd \\
\hline R 124 & -124 & 58.1 & 10.8 & 9.6 & 0.20 & 11.5 & 8.1 & 1.190 & 0.002 & 2.100 & 0.005 \\
\hline R 134 & -134 & 45.2 & 8.8 & 9.8 & 0.31 & nd & 10.3 & 1.196 & 0.003 & 2.098 & 0.008 \\
\hline R 136 & -136 & 40.4 & 11.8 & 11.2 & 0.15 & 29.0 & 12.2 & 1.180 & 0.003 & 2.109 & 0.006 \\
\hline R 140 & -140 & 30.7 & 6.9 & 10.0 & 0.29 & 25.0 & 14.2 & nd & nd & nd & nd \\
\hline R 148 & -148 & 43.6 & 10.4 & 9.6 & 0.25 & 32.5 & 12.2 & 1.186 & 0.002 & 2.092 & 0.004 \\
\hline R 157 & -157 & 45.1 & 12.6 & 11.7 & 0.38 & nd & 12.0 & 1.183 & 0.003 & 2.099 & 0.006 \\
\hline R 161 & -161 & 50.6 & 15.8 & 12.9 & 0.37 & 32.5 & 11.2 & 1.183 & 0.003 & 2.101 & 0.008 \\
\hline R 169 & -169 & 76.3 & 10.2 & 11.9 & 0.41 & 13.2 & 5.9 & nd & nd & nd & nd \\
\hline R 177 & -177 & 51.9 & 12.5 & 16.1 & 0.20 & 15.4 & 11.1 & 1.187 & 0.002 & 2.097 & 0.003 \\
\hline R 185 & -185 & 63.4 & 6.5 & 12.8 & 0.29 & 5.0 & 7.5 & 1.190 & 0.004 & 2.093 & 0.008 \\
\hline R 192 & -192 & 64.0 & 6.9 & 10.2 & 0.25 & 7.1 & 7.2 & 1.200 & 0.005 & 2.090 & 0.012 \\
\hline R 201 & -201 & 57.9 & 9.7 & 11.5 & 0.29 & 5.6 & 9.4 & nd & nd & nd & nd \\
\hline R 209 & -209 & 73.6 & 11.5 & 14.4 & 0.23 & 9.4 & 5.7 & 1.178 & 0.002 & 2.094 & 0.004 \\
\hline R 217 & -217 & 66.9 & 7.1 & 12.0 & 0.23 & 10.6 & 6.7 & 1.177 & 0.005 & 2.099 & 0.011 \\
\hline R 221 & -221 & 71.6 & 6.5 & 10.2 & 0.19 & 10.6 & 5.0 & 1.176 & 0.002 & 2.095 & 0.004 \\
\hline R 224 & -224 & 68.4 & 7.4 & 12.9 & nd & 10.4 & 6.3 & nd & nd & nd & nd \\
\hline R 233 & -233 & 75.6 & 6.6 & 20.6 & 0.21 & 10.6 & 4.6 & 1.177 & 0.003 & 2.095 & 0.008 \\
\hline R 241 & -241 & 74.5 & 5.9 & 39.4 & 0.30 & 12.8 & 6.3 & 1.172 & 0.004 & 2.099 & 0.008 \\
\hline R 247 & -247 & 59.3 & 7.4 & 29.6 & nd & 15.1 & 7.9 & nd & nd & nd & nd \\
\hline R 252 & -252 & 60.2 & 6.3 & 21.5 & 0.21 & 6.2 & 7.2 & 1.207 & 0.003 & 2.087 & 0.007 \\
\hline R 261 & -261 & 61.9 & 7.9 & 12.5 & 0.24 & 9.7 & 8.9 & 1.190 & 0.002 & 2.100 & 0.010 \\
\hline R 269 & -269 & 52.5 & 7.1 & 9.1 & 0.20 & 7.3 & 9.0 & 1.208 & 0.002 & 2.091 & 0.004 \\
\hline R 273 & -273 & 51.9 & 6.9 & 10.1 & 0.27 & 6.1 & 11.0 & nd & nd & nd & nd \\
\hline R 281 & -281 & 57.1 & 9.6 & 10.7 & 0.19 & 9.6 & 8.3 & 1.188 & 0.004 & 2.101 & 0.008 \\
\hline R 285 & -285 & 62.5 & 11.2 & 17.9 & 0.25 & 7.0 & 10.4 & 1.191 & 0.002 & 2.094 & 0.004 \\
\hline R 294 & -294 & 40.2 & 21.0 & 21.9 & 0.14 & 14.0 & 12.1 & 1.187 & 0.003 & 2.110 & 0.008 \\
\hline R 300 & -300 & 24.2 & 12.7 & 29.8 & 0.52 & 2.9 & 18.1 & 1.227 & 0.003 & 2.073 & 0.006 \\
\hline R 305 & -305 & 17.0 & 10.8 & 53.3 & 0.12 & 6.7 & 11.7 & 1.215 & 0.004 & 2.083 & 0.006 \\
\hline R 313 & -313 & 7.6 & 6.3 & 24.6 & 0.34 & 1.3 & 10.4 & nd & nd & nd & nd \\
\hline R 321 & -321 & 7.0 & 6.2 & 34.9 & 0.18 & 6.2 & 9.1 & 1.219 & 0.002 & 2.085 & 0.005 \\
\hline R 323 & -323 & 6.9 & 5.9 & 45.5 & 0.35 & 5.9 & 12.6 & 1.233 & 0.005 & 2.062 & 0.010 \\
\hline R 333 & -333 & 16.9 & 10.7 & 45.1 & 0.28 & 9.9 & 13.4 & 1.218 & 0.004 & 2.087 & 0.009 \\
\hline R 341 & -341 & 20.2 & nd & nd & nd & 16.3 & 18.9 & 1.199 & 0.003 & 2.106 & 0.009 \\
\hline R 345 & -345 & 21.6 & 10.9 & 47.1 & 0.11 & 7.4 & 14.7 & 1.206 & 0.002 & 2.100 & 0.005 \\
\hline R 350 & -350 & 21.5 & 10.4 & 40.2 & nd & 9.2 & 16.4 & nd & nd & nd & nd \\
\hline R 359 & -359 & 42.6 & 9.1 & 25.2 & 0.24 & 9.2 & 8.8 & 1.200 & 0.003 & 2.094 & 0.005 \\
\hline
\end{tabular}


Table 2 (Continued)

\begin{tabular}{|c|c|c|c|c|c|c|c|c|c|c|c|}
\hline Name & $\begin{array}{l}\text { Depth } \\
(\mathrm{cm})\end{array}$ & LOI\% & $\begin{array}{l}\mathrm{Cu} \\
\mu \mathrm{g} \mathrm{g}^{-1}\end{array}$ & $\begin{array}{l}\mathrm{Zn} \\
\mu \mathrm{g} \mathrm{g}^{-1}\end{array}$ & $\begin{array}{l}\mathrm{Cd} \\
\mu \mathrm{g} \mathrm{g}{ }^{-1}\end{array}$ & $\begin{array}{l}\mathrm{Pb} \\
\mu \mathrm{g} \mathrm{g}^{-1}\end{array}$ & $\begin{array}{l}\text { Sc } \\
\mu g_{g}^{-1}\end{array}$ & $\begin{array}{l}{ }^{206} \mathrm{~Pb} / \\
{ }^{207} \mathrm{~Pb}\end{array}$ & \pm & $\begin{array}{l}{ }^{208} \mathrm{~Pb} / \\
{ }^{206} \mathrm{~Pb}\end{array}$ & \pm \\
\hline R 366 & -366 & 57.2 & 10.1 & 17.6 & 0.31 & 8.5 & 7.5 & 1.194 & 0.004 & 2.092 & 0.008 \\
\hline R 375 & -375 & 57.0 & 7.1 & 12.7 & 0.19 & 8.6 & 7.5 & 1.189 & 0.003 & 2.099 & 0.005 \\
\hline R 379 & -379 & 45.6 & 12.6 & 21.8 & nd & 13.0 & 12.3 & nd & nd & nd & nd \\
\hline R 386 & -386 & 37.8 & 7.9 & 14.6 & 0.19 & 5.7 & 6.0 & 1.204 & 0.003 & 2.079 & 0.007 \\
\hline R 390 & -390 & 39.7 & 5.9 & 21.5 & 0.25 & 4.3 & 7.2 & 1.200 & 0.003 & 2.092 & 0.004 \\
\hline R 398 & -398 & 25.8 & 6.7 & 14.5 & 0.19 & 7.1 & 7.1 & 1.206 & 0.004 & 2.083 & 0.008 \\
\hline R 403 & -403 & 32.4 & 6.1 & 17.8 & 0.23 & 3.3 & 8.8 & 1.221 & 0.004 & 2.069 & 0.007 \\
\hline R 414 & -414 & 23.4 & 5.6 & 22.5 & 0.21 & 6.0 & 7.6 & nd & nd & nd & nd \\
\hline
\end{tabular}

nd: Not determined.

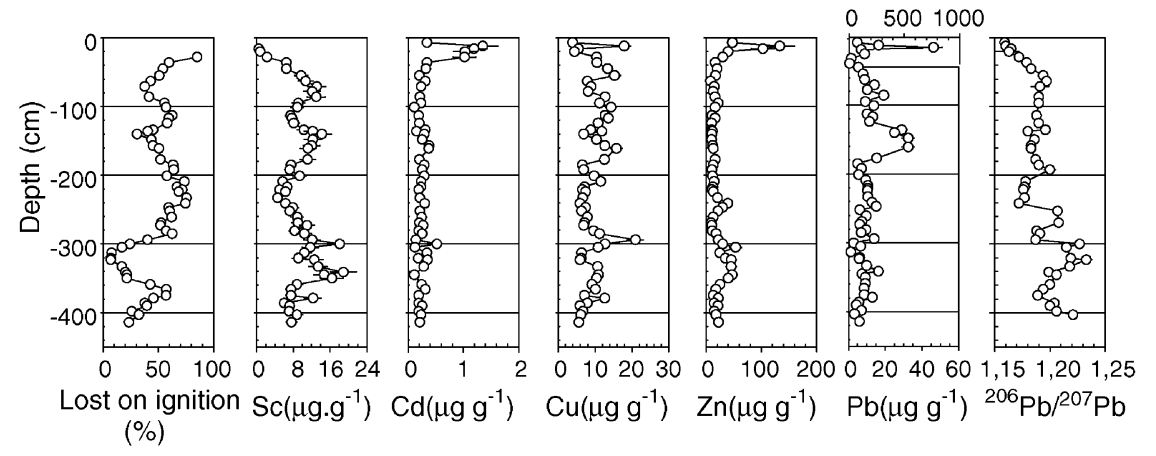

Fig. 3. Lost on ignition, scandium, cadmium, copper, zinc, lead and ${ }^{206} \mathrm{~Pb} /{ }^{207} \mathrm{~Pb}$ ratios plotted against depth. Note the break in the lead concentration axis. Most of errors represent less than the size of dots; otherwise the error bars represent a confidence level of $95 \%$.

classified as peat and muck interbedded (Kivinen, 1980; Moris, 1989) or as low-ash carbonaceous sediments with interbedded high ash carbonaceous sediments and peat layers (Andrejko et al., 1983), but this latter classification rather matches the use of peat as fuel for industry (Wüst et al., 2003).

Considering the whole core, $\mathrm{Sc}$ content is inversely correlated to LOI $\left(r^{2}=0.46, P<0.01\right)$, but the correlation is improved if only the uppermost $300 \mathrm{~cm}$ are taken into account $\left(r^{2}=0.89\right.$, $P<0.01$ ) (Fig. 4). The same observation is made with other lithophilic elements ( $\mathrm{La}, \mathrm{Th}, \mathrm{Cr}, \mathrm{Rb}$ and REE not presented here), which are all strongly correlated with $\mathrm{Sc}\left(r^{2}>0.85, P<0.01\right.$ for $\mathrm{Rb}$ and $r^{2}>0.96$ for the others).

\subsection{Heavy metals}

$\mathrm{Cd}, \mathrm{Zn}$ and $\mathrm{Pb}$ concentrations increase in the topmost $40 \mathrm{~cm}$ and peak in approximately the

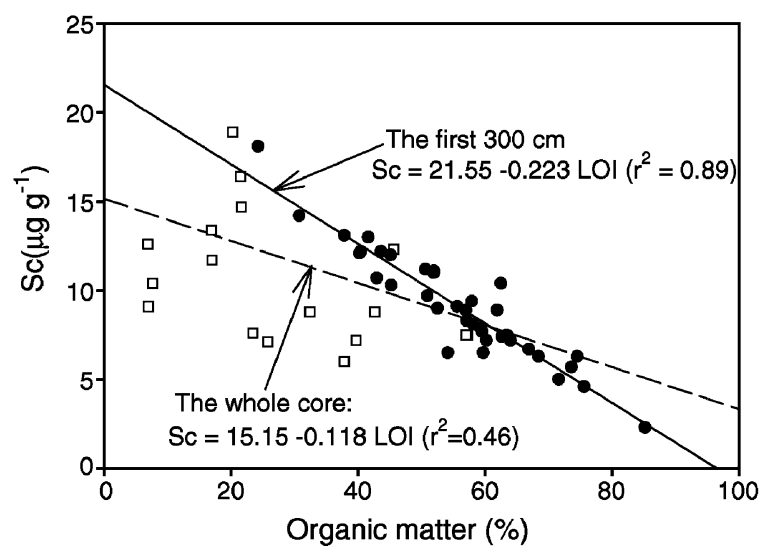

Fig. 4. Scandium content plotted against organic matter content; (O): the $300 \mathrm{~cm}$ topmost samples, $(\square)$ : the others. 


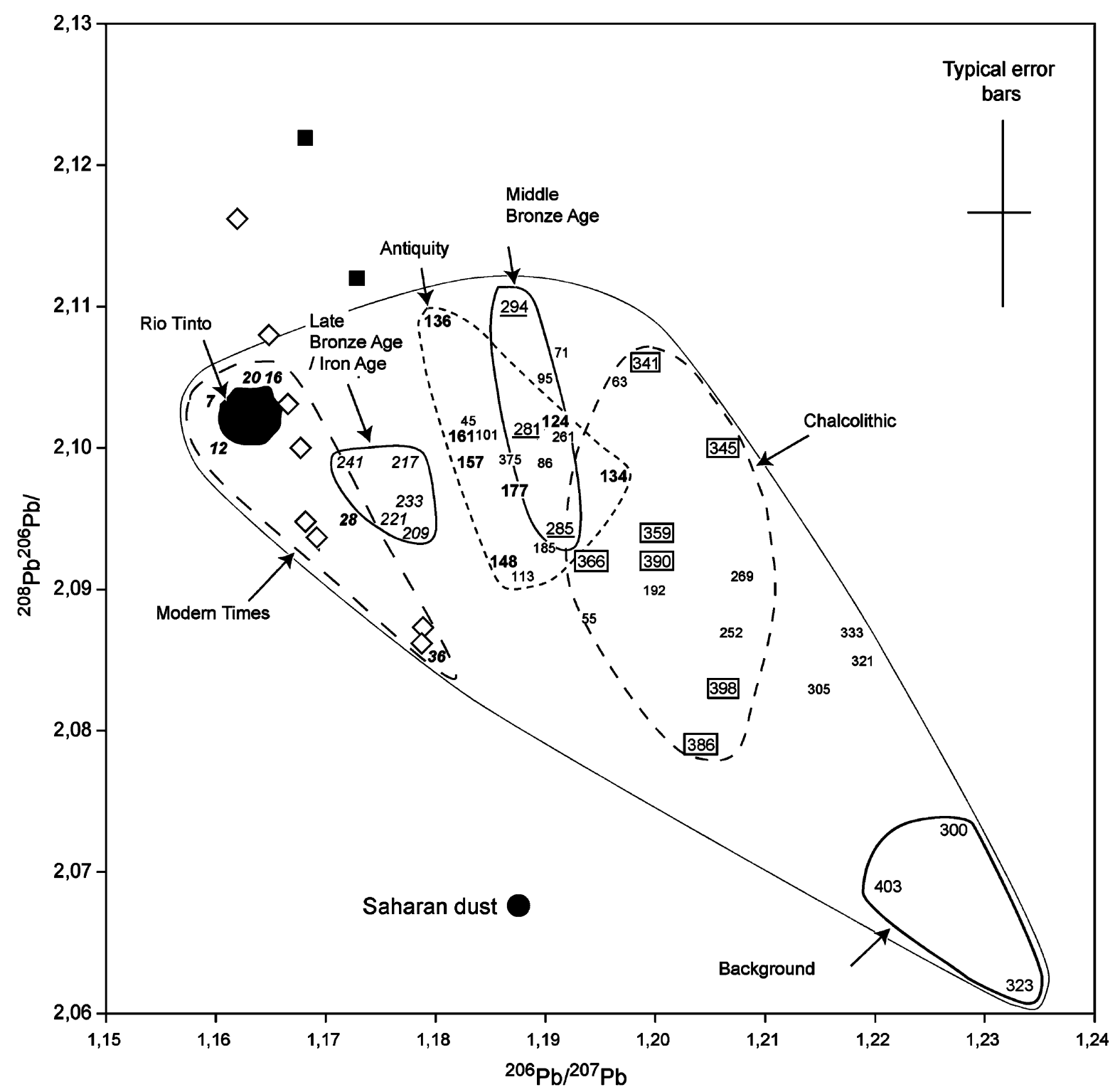

Fig. 5. ${ }^{208} \mathrm{~Pb} /{ }^{206} \mathrm{~Pb}$ vs. ${ }^{206} \mathrm{~Pb} /{ }^{207} \mathrm{~Pb}$ diagram. The peat samples are represented by their depth. Five clusters have been defined among the horizons featuring high $\mathrm{Pb} / \mathrm{Sc}$ and low ${ }^{206} \mathrm{~Pb} /{ }^{207} \mathrm{~Pb}$ ratios on the basis of the cultural periods in which they appear (see text for more details). The isotopic compositions of artefacts dating from the Late Bonze Age $(\diamond)$ and antiquity ( $\square$ ) (this study), and those of Saharan dusts (O) (Grousset et al., 1995) and Rio Tinto (Stos-Gale et al., 1995) are also plotted for further comparison.

same horizon at $1.35 \mu \mathrm{g} \mathrm{g}^{-1}, 133 \mu \mathrm{g} \mathrm{g}^{-1}$ and $765 \mu \mathrm{g} \mathrm{g}^{-1}$, respectively, then decrease to the surface (Fig. 3). Below, the $\mathrm{Cd}$ profile is rather flat, whereas $\mathrm{Zn}$ exhibits smooth variations with two peaks at 241 and $305-350-\mathrm{cm}$ depth. $\mathrm{Pb}$ rises more or less from the bottom to approximately $150-\mathrm{cm}$ depth, except for a fall in the detrital horizon (310-cm depth), before decreasing to 5 
$\mu \mathrm{g} \mathrm{g}^{-1}$ at $45-\mathrm{cm}$ depth. No clear tendencies are detected in the $\mathrm{Cu}$ profile. Its maximum value (21 $\mu \mathrm{g}^{-1}$ ) does not occur in the top horizons, but at 294-cm depth. $\mathrm{Cd}, \mathrm{Cu}$ and $\mathrm{Pb}$ do not present any relationship with LOI as indicated by insignificant Spearman's coefficient values, whereas $\mathrm{Zn}$ shows a weak inverse correlation $\left(r_{\mathrm{sp}}=-0.347\right.$, $P<0.01$ ).

\subsection{Lead isotopic compositions}

${ }^{206} \mathrm{~Pb} /{ }^{207} \mathrm{~Pb}$ ratios vary widely from 1.233 , in the most detrital layers (300-320-cm depth), to 1.159 at the top (Fig. 3). This evolution is not regular but presents five major shifts toward low ${ }^{206} \mathrm{~Pb} /{ }^{207} \mathrm{~Pb}$ ratios: (i) at approximately $375-\mathrm{cm}$ depth; (ii) between 280 and 290-cm depth; (iii) between 209 and 241-cm depth; (iv) at 160-cm depth; and finally (v) an almost linear decline, from $63 \mathrm{~cm}$ to the top. Reported on a ${ }^{208} \mathrm{~Pb} /{ }^{206} \mathrm{~Pb}$ vs. ${ }^{206} \mathrm{~Pb} /{ }^{207} \mathrm{~Pb}$ diagram (Fig. 5), peat samples form a triangle rather than falling on a characteristic binary mixing line. The samples from the most detrital horizons (300, 403, 323-cm depth) define the first summit of the triangle featured by highest ${ }^{206} \mathrm{~Pb} /{ }^{207} \mathrm{~Pb}$ and lowest ${ }^{208} \mathrm{~Pb} /{ }^{206} \mathrm{~Pb}$ ratios. The second summit corresponds to samples having high ${ }^{208} \mathrm{~Pb} /{ }^{206} \mathrm{~Pb}$ ratios (approx. 2.105) with intermediate ${ }^{206} \mathrm{~Pb} /{ }^{207} \mathrm{~Pb}$ values (approx. $1.19-1.20$ ). The last one matches the uppermost samples (7$20-\mathrm{cm}$ depth) with the lowest ${ }^{206} \mathrm{~Pb} /{ }^{207} \mathrm{~Pb}$ ratios $(<1.17)$ and ${ }^{208} \mathrm{~Pb} /{ }^{206} \mathrm{~Pb}$ ratios of approximately 2.100-2.105. Artefacts produced during the Late Bronze Age and Antiquity are also reported on the diagram for further comparison.

\section{Discussion}

\subsection{Origin of mineral material and assessment of anthropogenic contribution}

Previous studies have shown that mineral matter may affect the distribution of metals in a peat core (Shotyk, 1996a,b; Weiss et al., 1997). The extent of anthropogenic contribution by comparison to natural contribution can, however, be estimated by normalising total metal concentrations to a conser- vative element, which has no anthropogenic origin. Lithophilic elements such as Sc, but also $\mathrm{Zr}$, Ti, Al (Martínez-Cortizas et al., 1997, 2002; Schettler and Romer, 1998; Kempter and Frenzel, 2000; Shotyk et al., 2001, 2002a,b; Shotyk, 2002; Weiss et al., 2002) or ash content (West et al., 1997; Alfonso et al., 2001) are generally used for normalisation. This procedure implicitly assumes that natural Metal/Sc ratios of natural inorganic material are constant over time. However, atmospheric inorganic matter derives from sources, which may vary according to climate and human land occupation, thus affecting the consistency of natural Metal/Sc ratios (Shotyk et al., 2002a). As a matter of fact, large variations in ratios of lithophilic elements, such as $\mathrm{La} / \mathrm{Sc}$, were reported in an ombrotrophic peat bog in the Jura Mountains, and were interpreted as being the result of changes in the nature of atmospheric mineral inputs (Shotyk et al., 2001).

In the mineral-dominated Quinto Real core, the $\mathrm{La} / \mathrm{Sc}$ and $\mathrm{Th} / \mathrm{Sc}$ ratios exhibit only small variations around upper continental crust (UCC) values $(\mathrm{La} / \mathrm{Sc}=4.61$ and $\mathrm{Th} / \mathrm{Sc}=1.47$, Wedepohl, 1995) (Fig. 6). Moreover, when normalized to the shales, REEs display typical flat patterns (not shown here), reflecting a constant crust-derived origin. Thus, local inputs have presumably always predominated, suggesting constant REE patterns and $\mathrm{Metal} / \mathrm{Sc}$ ratios over time. The values of these latter could be defined as reference before any enrichment factor or anthropogenic flux calculations. They will preferably be drawn from a given location rather than from earth crust compositions, because a global average cannot account for the local variations in rock chemistry (Weiss et al., 1997). In addition, chemical fractionation of the elements by physical fractionation during dust transport has been suggested, so that using crustal proportions as reference value for normalization may be meaningless (Martínez-Cortizas et al. 2002). At Quinto Real, samples do not exhibit constant Metal/Sc values at the bottom of the core (Fig. 7). Had they been present, suggesting uncontaminated horizons, they could have been used as reference values. In Fig. 4, the deficit in scandium below $300 \mathrm{~cm}$ by comparison to the organic matter 

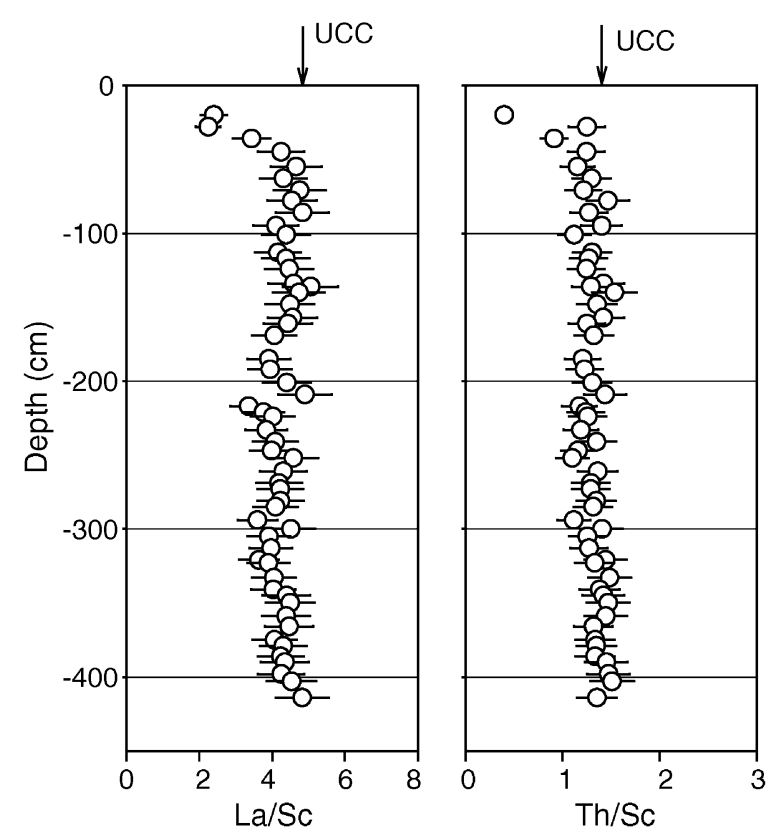

Fig. 6. Evolution of $\mathrm{La} / \mathrm{Sc}$ and $\mathrm{Th} / \mathrm{Sc}$ ratios with depth in the Quinto Real core. The values of the upper continental crust (UCC) (Wedepohl, 1995) are also given. The error bars represent a confidence level of $95 \%$.

content would rather indicate the presence of an authigeneous mineral phase, possibly resulting from water circulation as minerotrophic peatlands are not hydrologically isolated from the substratum (Shotyk, 1996a,b). For these reasons, consistent values for natural Metal/Sc ratios are difficult to determine and enrichment factor or anthropogenic fluxes cannot be properly calculated. Since quantitative information is not available, our aim is now to determine if the Metal/Sc ratio profiles can at least be interpreted qualitatively. Even if our suggestion that Metal/Sc ratios of natural inorganic material are constant over time were to prove unfounded, it is still logical to suppose that any variations would not significantly affect overall Metal/Sc ratios observed in polluted peat samples.

\subsection{Evaluation of metal record integrity}

In a ${ }^{208} \mathrm{~Pb} /{ }^{206} \mathrm{~Pb}$ vs ${ }^{206} \mathrm{~Pb} /{ }^{207} \mathrm{~Pb}$ diagram, the natural (or background) end-member corresponds to samples possessing highest ${ }^{206} \mathrm{~Pb} /{ }^{207} \mathrm{~Pb}(1.22-$ 1.23) and lowest ${ }^{208} \mathrm{~Pb} /{ }^{206} \mathrm{~Pb}$ ratios $(2.06-2.07)$ (Fig. 5). Such values are comparable to those previously published for atmospheric inputs of crust-derived lead in Western Europe $\left({ }^{206} \mathrm{~Pb} /{ }^{207} \mathrm{~Pb}\right.$ : 1.195-1.275) (Shotyk et al., 1998; Dunlap et al., 1999; Camarero et al. 1998; Alfonso et al., 2001; Martínez-Cortizas et al., 2002). The other horizons have been affected by one (or several) less radiogenic components. Five clusters can be defined
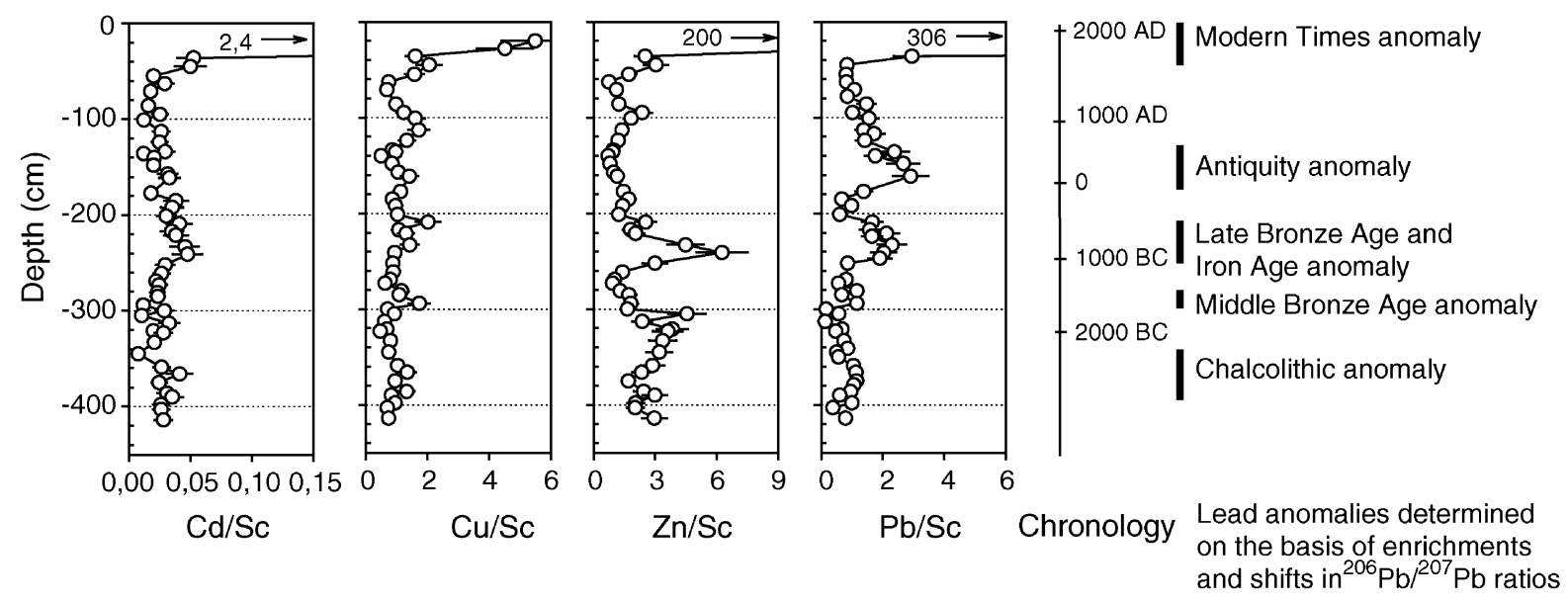

Fig. 7. $\mathrm{Cd} / \mathrm{Sc}, \mathrm{Cu} / \mathrm{Sc}, \mathrm{Zn} / \mathrm{Sc}$ and $\mathrm{Pb} / \mathrm{Sc}$ ratios vs. depth in the Quinto Real core. The error bars represent a confidence level of $95 \%$. 
among the horizons featuring high $\mathrm{Pb} / \mathrm{Sc}$ and low ${ }^{206} \mathrm{~Pb} /{ }^{207} \mathrm{~Pb}$ ratios on the basis of the cultural periods in which they appear (cf. Figs. 7 and 8): Chalcolithic (samples at 341, 345, 359, 366, 386, 390, 398-cm depth), Middle Bronze Age (281, 285, $294 \mathrm{~cm}$ depth), Late Bronze Age-Iron Age $(209,217,221,233,241-\mathrm{cm}$ depth $)$, Antiquity $(124,134,136,148,157,161,177-\mathrm{cm}$ depth) and Modern Times (7, 12, 16, 20, 28, 36-cm depth) (Fig. 5). It is clear that the lead enrichments observed in Chalcolithic horizons cannot be explained by a simple mineral dissolution of the substratum because their isotopic compositions are significantly different from those of the background. Similarly, Saharan dust inputs, very frequent in the Basque country, cannot be invoked given that the isotopic signature of this source (Grousset et al., 1995) does not fit with the data (Fig. 5). The presence of a sandy horizon at approximately $310 \mathrm{~cm}$ depth may have strongly facilitated the downward post-depositional translocation of lead from the Middle Bronze Age horizons. The intermediate position of the Chalcolithic group between the Middle Bronze Age horizons and the background well supports this thesis. Another possible scenario would be the real occurrence of anthropogenic inputs starting as early as the Chalcolithic. The interruption in the $\mathrm{Pb} / \mathrm{Sc}$ trend observed approximately $310-\mathrm{cm}$ depth in Fig. 7 would, therefore be due to the dilution of anthropogenic inputs by strong deposition of detrital inorganic matter. The study of a nearby core presenting no such variation in organic matter content could help resolve this question.

It is noteworthy that the above-mentioned clusters and the background as a whole form a triangle rather than a line (Fig. 5). The sequence in which the clusters appear, from low to high ${ }^{206} \mathrm{~Pb} /{ }^{207} \mathrm{~Pb}$ signatures (Modern Times, Late Bronze Age, Antiquity, Middle Bronze Age), does not correspond to any chronological order, so that it is impossible to explain their position as the result of a major migration of lead. It implies rather the result of a change in the type of mineral exploitation during these periods. Other works have already reported a very limited downward migration for Pb (Dumontet et al., 1990; Farmer et al., 1997; Vile et al., 1999), in part because almost all of the cationic species of this metal are bound to organic phase, which considerably reduces its mobility in peat (Shotyk, 1996b; Vile et al., 1999). Even in a mineral-dominated marsh in Aquitaine (with ash content up to 94\%), the lead isotopic record yielded similar results to those obtained in ombrotrophic peat bogs and ice cores (Alfonso et al., 2001), and were quite consistent with the wellaccepted assessment of world lead production during the last 5000 years (Settle and Patterson, 1980). Similarly, the comparison of both ombrotrophic and minerotrophic peat deposits in the Jura Mountains also demonstrated the relative immobility of lead and the possibility of using its record in minerogenic peatlands as a surrogate of past anthropogenic inputs in certain circumstances, such as the predominance of anthropogenic inputs over both detrital contribution and mineral dissolution of the substratum (Shotyk 1996a,b; Weiss et al., 1999; Shotyk, 2002). Although our core presents high ash content, the lead record at the considered time resolution appears to be well preserved, at least within the uppermost $300 \mathrm{~cm}$. However, the duration of identified pollution phases may have been overestimated because of the release of lead from polluted soils over a long period of time after major atmospheric inputs.

For other metals the situation is more complex and different behaviours have been suggested depending on organic matter content, $\mathrm{pH}$ and fluctuations in redox potential (Shotyk, 1996b). Although copper ore deposits have been extensively mined in the valley since at least Roman Times, no clear trend in $\mathrm{Cu} / \mathrm{Sc}$ ratios can be observed along the profile, except at the surface (Fig. 7). The present core does not seem suitable for the reconstruction of past atmospheric $\mathrm{Cu}$ inputs, unlike others previously reported (Kempter and Frenzel, 2000; Mighall et al., 2002). Like copper, $\mathrm{Zn}$ is an essential constituent for plants, and bioaccumulation processes may influence its distribution pattern, so that it is generally considered as a mobile metal, or at least as more susceptible to post-depositional redistribution than lead (Martínez-Cortizas et al., 1997). Here the $\mathrm{Zn} / \mathrm{Sc}$ ratio profile also exhibits positive shifts in the Late Bronze Age/Iron Age and Modern Times but none is observed during Antiquity. Cadmium is not 


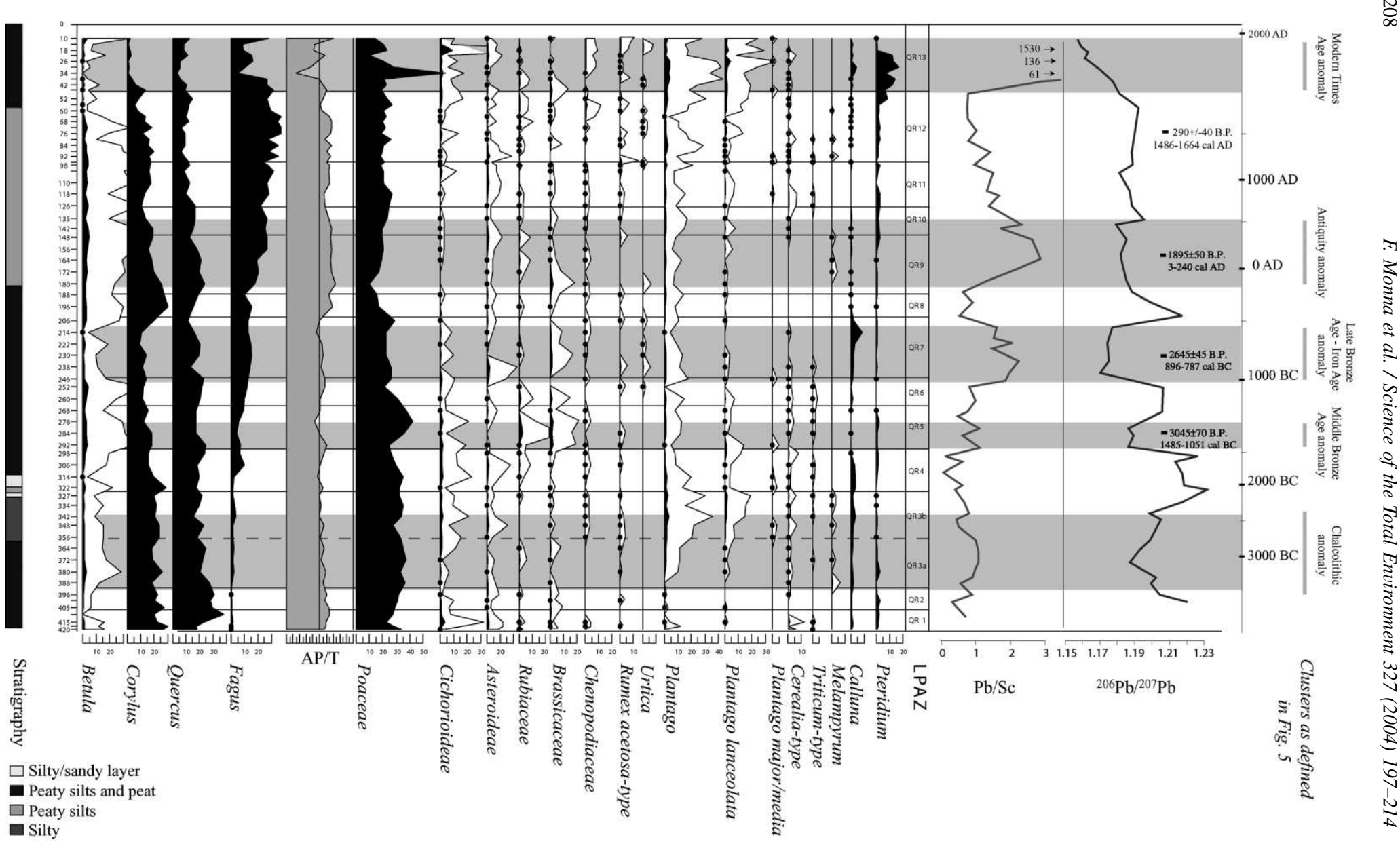

Fig. 8. Pollen record of the Quinto Real core (from Galop et al., 2001). $\mathrm{Pb} / \mathrm{Sc}$ and ${ }^{206} \mathrm{~Pb} /{ }^{207} \mathrm{~Pb}$ ratios are reported to make easier historical reconstruction. The relative pollen diagram is divided into Local Pollen Assemblage Zones (LPAZ) based on relative change in land-use pollen indicators according to Behre (1981) and on relative change between trees and open-land indicators. 
influenced as much as zinc and copper by plant uptake, which makes it closer to lead. Positive anomalies occur during the Late Bronze Age/Iron Age and Modern Times, as with $\mathrm{Zn}$ and $\mathrm{Pb}$, but none is observed during Antiquity and the Middle Ages. In any case, it is hazardous to use the $\mathrm{Zn}$, $\mathrm{Cu}$ and $\mathrm{Cd}$ profiles for historical purposes because these elements do not possess isotopic features comparable to lead, which would allow their degree of migration to be assessed.

\subsection{Towards a historical interpretation}

\subsubsection{Prehistoric record}

In QR 1 (cf. Fig. 8), or in other words prior to ca 3000 BC, the presence of Cerealia-type, Triticum-type and Plantago lanceolata in the pollen record shows significant cereal cultivation and human settlements. Later, the decline of oak (Quercus) combined with the extension of birch (Betula), a heliophilic tree, suggest a progressive deforestation which could be at the origin of the detrital layer recorded at $310-\mathrm{cm}$ depth, around cal. 2000 BC.

The ${ }^{206} \mathrm{~Pb} /{ }^{207} \mathrm{~Pb}$ and $\mathrm{Pb} / \mathrm{Sc}$ ratios of the Middle Bronze Age (QR5) and Late Bronze Age/Iron Age (QR 7) samples, respectively, cal. 1500-1300 BC and cal. 1000-600 BC, indicate significant anthropogenic inputs. Simultaneously, oak and hazel (Corylus) diminish while traces of agropastoral and slash-and-burn activities (Plantago lanceolata, Plantago major/media, Melampyrum, Rumex) decrease or are simply absent. Between these two phases (QR6, cal. 1300-1000 BC), Pb/ $\mathrm{Sc}$ and ${ }^{206} \mathrm{~Pb} /{ }^{207} \mathrm{~Pb}$ ratios are more crustal, and signs of reforestation are observed. Both geochemical and pollen records are in good agreement with the sparse archaeological knowledge available. In the Middle Bronze Age, and more precisely during the 15 th and 14 th centuries BC, metallurgical activity increased in the Southern French Atlantic region, with high production of bronze alloys (Coffyn et al., 1995). Regional smelting and/or mining probably decreased from 1100 BC (Cantet, 1991), to start again in the Final Bronze Age, as proved by the abundant production of ornamental artefacts. The wealth of copper in the polymetallic district of Banca may, therefore have attracted early miners, although direct field evidence of Bronze Age exploitation is still lacking in the valley, apart from the discovery of a prehistoric mallet used to crush minerals (Dupré et al., 1993). Prehistoric exploitations are likely to have suffered from considerable alteration due to a humid climate on steep slopes, or more certainly to have been destroyed by later occupation. At that time lead was not exploited for itself but was emitted into the atmosphere in significant amounts subsequent to mineral extraction and smelting of other metals, so it could be a good marker for local or regional prehistoric metallurgy. Such contaminations dating as far back as the Bronze Age have been recorded in natural archives in the Jura Mountains (Weiss et al., 1997), the North-Western Iberian Peninsula (Martínez-Cortizas et al., 1997, 2002), the overbank sediments of the River Weser (Monna et al., 2000a), and in the French Morvan massif (Blanchot et al., 2001). The isotopic signatures of Late Bronze Age/Iron Age peat samples fall into line with those of contemporary bronze and copper artefacts (rings, a bracelet, pins, a sword, and other bronze fragments) recently found in the Basque country (Fig. 5), even though they may have been produced using metals locally extracted or acquired by trading. Significant changes in metalworking practices are also suggested by the change of isotopic signatures between Middle and Late Bronze Age (Fig. 5), but the strongest clue to local metalworking occurrence is given by the concomitance of anthropogenic lead enrichments and deforestations. As the latter are not consecutive to agro-pastoral extensions, they are interpreted as the result of mounting energy demands for mining and smelting, like those already reported in several parts of Pyrenees (Galop and Jalut, 1994), in the Swiss Jura Mountains for iron metallurgy (Richard and Eschenlhor, 1998), and more recently in the French Morvan massif (Blanchot et al., 2001; Monna et al., 2004).

\subsubsection{Antiquity}

Another major anthropogenic phase is pinpointed by $\mathrm{Pb} / \mathrm{Sc}$ and ${ }^{206} \mathrm{~Pb} /{ }^{207} \mathrm{~Pb}$ from ca cal. $200 \mathrm{BC}$ to approximately $200 \mathrm{AD}$ (Fig. 7). At that time, oak and hazel decrease while beech seems to spread. Moderate signs of deforestation appear 
again without any indication of significant agricultural extension. Such an intensification of anthropogenic atmospheric inputs in Antiquity has already been reported at the continental scale, in the Pyrenean region (Ariès, 2001) as well as far beyond the Mediterranean area, as demonstrated by the studies performed in Greenland (Hong et al., 1994; Rosman et al., 1997), Sweden (Brännvall et al., 1999; Renberg et al., 2000, 2001), Northern Spain (Martínez-Cortizas et al., 2002) and the Jura Mountains (Shotyk et al., 1998). In fact, these signals are so ubiquitous in Southern and Western Europe that certain authors have suggested their use as a chronological marker in sediment deposits (Alfonso et al., 2001; Renberg et al., 2001). They are often interpreted as the result of long-range transport of contaminants originating from Spain, especially when local mining is lacking and lead isotopic compositions are compatible with those of Rio Tinto, Southern Spain, one of the major mining sites (Stos-Gale et al., 1995); Hispania accounting for almost $40 \%$ of the worldwide $\mathrm{Pb}$ production during the Roman Empire (Nriagu, 1983).

The $\mathrm{Pb} / \mathrm{Sc}$ peak observed in the core corresponds well with the exploitation of iron, copper, silver and lead from the metallurgical and mining sites of the Baigorri Valley well known in Antiquity (Machot, 1995). Apart from Roman industrial activity, numerous other small workshops were found throughout the valley of Urepel (Beyrie et al., in press). Because of the abundance of this indigenous exploitation and the incompatibility of lead isotopic signatures in peat samples with those of the Rio Tinto district (cf. Fig. 5), major influence from remote sources is not to be considered here. Any long-range input was undoubtedly masked by dominating anthropogenic local inputs. This is in good agreement with another recent study undertaken in the Lake Redó, Central Pyrenees-Spain, which clearly identified a phase of pollution, attributed to local mining operations, starting approximately $670 \mathrm{BC}$ and reaching a maximum at approximately $660 \mathrm{AD}$; in other words peaking after Roman times, a period in which lead production was at a minimum in Europe (Camarero et al., 1998). Long-range transport of lead from the Rio Tinto region should appear on the flank of this peak but was not noticeable, probably because this source was also masked by dominant local emissions. The isotopic compositions of metallic tool fragments found in the Roman gallery of the Banca mine support this hypothesis since such signatures might correspond to the anthropogenic end-member which shifted isotopic ratios of peat samples towards less radiogenic signatures (cf. Fig. 5). The decline of oak can be explained by deforestation for metallurgical operations. Moreover, anthraco-analysis has established that charcoal production within the valley mainly focussed on this species (Galop et al., in press).

Human-derived lead deposition lasted for at least 400 years and did not collapse as brutally as elsewhere at the fall of the Roman Empire, possibly because the Romanisation of the Basque country had never been intense. Another explanation could also be a delay due to weathering of polluted soils by small streams, which temporarily feed the Quinto Real peatland area.

\subsubsection{Medieval to modern time}

After a long decline throughout the Middle Ages, $\mathrm{Pb} / \mathrm{Sc}$ ratios increase markedly from the late 16th and early 17 th century $\mathrm{AD}$, coinciding with the decrease in ${ }^{206} \mathrm{~Pb} /{ }^{207} \mathrm{~Pb}$ ratios (Fig. 8). This period is abundantly mentioned in textual archives as an intense phase of metallurgical activity in the Basque country, and more particularly in the Baigorry valley. The copper foundry of Banca started operating in 1747. Most Basque forests were dedicated to charcoal production, as demonstrated by abundant charcoal-kiln remains in present forest areas of the Aldudes valley. Yet metalworking almost totally collapsed in the middle of the 19th century. Forest taxa slump when metalworking peaked, demonstrating intense wood charcoal consumption for energy production. Recent pollution has been recorded too, but its chronology is difficult to reconstruct accurately because ${ }^{14} \mathrm{C}$-based chronology is not detailed enough in topmost horizons. However, isotopic signatures at the surface of the core $\left({ }^{206} \mathrm{~Pb} /{ }^{207} \mathrm{~Pb}=\right.$ 1.159) probably illustrate the impact of allochtoneous less radiogenic anti-knock compounds added until recently to leaded gasoline. 


\section{Conclusion}

Although the origin of the earliest geochemical anomaly, recorded in Chalcolithic levels, remains unknown, two later anomalies, identifiable in Bronze Age levels, are almost certainly related to mining and smelting. The first episode, dating from the Middle Bronze Age, would probably not have been detected by the sole measurement of concentrations. Lead isotopes, however, are very sensitive to such low contaminations (Munksgaards and Parry, 1998), so that their use offers new possibilities for the recognition of precursor mining operations. The second episode occurred during the Late Bronze Age/Iron Age, at a time when metalworking was growing in magnitude throughout Western Europe. Both of these phases are accompanied by local signs of deforestation, not strictly related to agro-pastoral extensions. The strong impact of human activity during Antiquity in the nearby surroundings is clearly traced by geochemical and, to a lesser extent, pollen records. Lead emitted locally has dominated over remote sources, such as lead ore deposits intensively exploited by the Romans in Southern Spain. This latter source, often invoked as a major contributor to lead anomalies observed in European natural archives, has perhaps sometimes been overestimated because the presence of minor, but local, exploitations may have acted as point-sources. In Modern Times, human activity in the valley, in part related to mining and smelting, strongly impacted the nearby environment, as demonstrated by the drastic modification of plant cover and considerable metal pollution, with lead reaching concentrations up to $765 \mu \mathrm{g} \mathrm{g}^{-1}$.

Combining geochemistry, palynology, and archaeological knowledge allows interpretations to be extended. If the trustworthiness of the metal record can be verified, high ash minerogenic peatlands may be successfully used to document ancient mining exploitation and metallurgy, even though the information they provide is more qualitative than quantitative. The duration of pollution phases might be overestimated because of the release of lead from polluted soils over a long period of time after mining and/or smelting operations ceased. However, in addition to the evidence furnished by lead isotopic signatures, the good agreement, in our case, between interpretations from field data and archaeological knowledge (acquired independently) confirms the reliability of the lead signal, at least over the last four millennia.

\section{Acknowledgments}

This work is part of the research program entitled 'Palaeo-environment and dynamics of the anthropisation in the Basque Mountains (Dir. D. Galop)' funded by the Ministry of Culture (Aquitania Archaeological Survey). We would like to thank A. Bidard, G. Bossuet, A. Lopez Saez for their assistance in the field, P. Birringer for pollen preparation, P.-Y. Favargé and D. Vignati for their precious help during ICP-MS measurements, and P. Steinmann for his very helpful comments.

\section{References}

Alfonso S, Grousset F, Massé L, Tastet J-P. A European lead isotope signal recorded from 6000 to 300 years BP in coastal marshes (SW France). Atmosph Environ 2001;35:3595-3605.

Ambert, P., Coularou, J., Cert, C., Guendon, J.-L., Bourgarit, D., Mille, B., Dainat, D., Houlès, N., Baumes, B., Le plus vieil établissement de métallurgistes de France (IIIe millénaire av. J.-C.): Péret (Hérault), C.R. Palevol, 2002;1:64-74.

Andrejko MJ, Fiene F, Cohen AD. Comparison of ashing techniques for determination of the inorganic content of peatsm. In: Jarret PM, editor. Testing of peats and organic soils. Philadelphia: American Society for Testing and Materials, 1983. p. 5-20.

Ariès S. 2001. Mise en évidence de contaminations métalliques historiques à partir de l'étude d'enregistrements sédimentaires de lacs de haute montagne, Ph.D. University Toulouse. p. 278 .

Behre, K.-E., 1981, The interpretation of anthropogenic indicators in pollen diagrams. Pollen et Spores, XXIII, 2:225245.

Beyrie A, Galop D, Monna F, Mougin V, La métallurgie du fer au Pays Basque durant l'Antiquité. Etat des connaissances dans la vallée de Baigorri. In press Aquitania.

Blanchot, C, Guillaumet, J -P, Monna, F, Petit, C, Lévêque, J, Dominik, J, Historical reconstruction of metallic pollution using a geo-ombrogenic peat bog in Eduens Gallic territory (Bibracte, France). Second European Meeting on Environmental Chemistry. 2001; pp. 12-15.

Brännvall M-L, Bindler R, Emteryd O, Nilsson M, Renberg I. Stable isotope and concentration records of atmospheric lead 
pollution in peat and lake sediments in Sweden. Water Air Soil Poll 1997;100:243-252.

Brännvall M-L, Bindler R, Renberg I, Emteryd O, Bartnicki $\mathrm{J}$, Billström K. The medieval metal industry was the cradle of modern large-scale atmospheric lead pollution in Northern Europe. Environ Sci Technol 1999;33:4391-4395.

Camarero L, Masqué P, Devos W, Ani-Ragolta I, Catalan J, Moor HC, Pla S, Sanchez-Cabeza JA. Historical variations in lead fluxes in the Pyrenees (North-East Spain) from a dated lake sediment core. Water Air Soil Poll 1998;105:439_ 449.

Cantet J-P. L'âge du bronze en Gascogne gersoise, Archéologies, No. 4, Archéologies Vesuna, 1991; p. 240.

Chapman J-C, Tylecote R-F. Early copper in the Balkan. Proc Prehist Soc 1983;49:373-379.

Coffyn A, Moreau J, Bouris J-R. Les dépôts de bronze de Soulac-sur-mer. Aquitania 1995;13:7-31.

Degryse Ph, Muchez P, Six S, Waelkens M. Identification of ore extraction and metal working in ancient times: a case study of Sagalassos (SW Turkey). J Geochem Explor 2003;77:65-80.

Dumontet S, Lévesque M, Mathur SP. Limited downward migration of pollutant metals $(\mathrm{Cu}, \mathrm{Z}, \mathrm{Ni}, \mathrm{Pb})$ in acidic virgin peat soils near a smelter. Water Air Soil Poll 1990;49:329-342.

Dunlap CE, Steinnes E, Flegal AR. A synthesis of lead isotopes in two millenia of European air. Earth Planet Sci Lett 1999;167:81 -88.

Dupré E, Parant D, Saint-Arroman C, Tobie J-L, 1993. Note sur un site minier et métallurgique antique de la commune d'Urepel (Pyrénées-Atlantiques), Cahiers du G.A.P.O., 12: pp. 91-100.

Eades LJ, Farmer JG, MacKenzie AB, Kirika A, Bailey-Watts AE. Stable lead isotopic characterization of the historical record of environmental lead contamination in dated freshwater lake sediment cores from Northern and Central Scotland. Sci Tot Environ 2002;292:55-67.

Espi E, Boutron CF, Hong S, Pourchet M, Ferrari C, Shotyk $\mathrm{W}$, Charlet $\mathrm{L}$. Changing concentrations of $\mathrm{Cu}, \mathrm{Zn}, \mathrm{Cd}$, and $\mathrm{Pb}$ in a high altitude peat bog from Bolivia during the past three century. Water Air Soil Poll 1997;100:289-296.

Farmer JG, Mackenzie AB, Sugden CL, Edgar PJ, Eades LJ. A comparison of the historical lead pollution records in peat and freshwater lake sediments from Central Scotland. Water Air Soil Poll 1997;100:253-270.

Gale N-H, Stos-Gale Z-A, Livov P, Dimitov M, Todorov T, 1991. Recent studies of neolithic copper ores and artefacts in Bulgaria. In: Découverte du métal. Eluère, Mohen dir, Paris, (ed.). Picard, coll. 'Millénaires', pp. 49-75.

Galop D, Jalut G. Differential human impact and vegetation history in two adjacent Pyrenean valleys in the Ariège basin, Southern France, from 3000 BP to the present. Veg Hist Archaeobot 1994;3:225-244.

Galop D, Monna F, Beyrie A, Carozza L, Marembert F, Parent G, Mougin V, (in press), Métallurgie et histoire de l'environnement au cours des cinq derniers millénaires en Pays basque nord (Vallée de Baigorri, P.-A., France): premiers résultats d'une approche interdisciplinaire. Archeologia Postmedievale.

Galop D, Tual M, Monna F, Dominik J, Beyrie A. Pour une histoire des activités métallurgiques en montagne basque. Les apports d'une démarche intégrée alliant palynologie et géochimie isotopique du plomb. Sud Ouest Européen 2001;11:3-15.

Gapillou C., Vers une apporche métallogénique d'une region Presque oubliée. Les minéralisation à: $\mathrm{Cu}, \mathrm{Ag}, \mathrm{Pb}, \mathrm{Zn}$ et les sidérites du paléozoïque et du trias du Pays Basque français entre Aïnhoa et Banca. 1981. Ph.D Thesis, University of Paris 6, 275.

Glooschenko WA, Holloway L, Arafat N. The use of mires in monitoring the atmospheric deposition of heavy metals. Aquat Bot 1986;25:179-190.

Grousset FE, Quetel CR, Thomas B, Donard OFX, Lambert CE, Guillard F, Monaco A. Anthropogenic vs. lithogenic origins of trace elements (As, $\mathrm{Cd}, \mathrm{Pb}, \mathrm{Rb}, \mathrm{Sb}, \mathrm{Sc}, \mathrm{Sn}, \mathrm{Zn}$ ) in water column particles: North-Western Mediterranean Sea. Mar Chem 1995;48:291-310.

Hong S, Candelone J-P, Patterson CC, Boutron CF. Greenland ice evidence of hemispheric lead pollution two millennia ago by Greek and Roman civilizations. Science 1994;265:1841-1843.

Jones JM, Hao J. Ombrotrophic peat as a medium for historical monitoring of heavy metal pollution. Environ Geochem Health 1993;15:67-74.

Kempter H, Görres M, Frenzel B. Ti and Pb concentrations in rainwater-fed bogs in Europe as indicators of past anthropogenic activities. Water Air Soil Poll 1997;100:367-377.

Kempter H, Frenzel B. The impact of early mining and smelting on the local tropospheric aerosol detected in ombrotrophic peat bogs in the Harz, Germany. Water Air Soil Poll 2000;121:93-108.

Kivinen E. 1980. Proposal for a general classification of virgin peat, In: Grubich, D.M. Farnham, R.S., Itkoten, B. (Eds). Proceedings of the 6th International Peat Congress, Duluth, Minnesota, USA. International Peat Society, Duluth, USA, p. 47.

Lee JA, Tallis JH. Regional and historical aspects of lead pollution in Britain. Nature 1973;245:216-218.

Machot P., 1995. Mines et établissements métallurgiques da Banca, Biaritz/Saint-Etienne de Baïgorri, Editions Izpegi, p. 406.

MacKenzie AB, Logan EM, Cook GT, Pulford ID. A historical record of atmospheric depositional fluxes of contaminants in West-Central Scotland derived from an ombrotrophic peat core. Sci Tot Environ 1998a;222:157-166.

MacKenzie AB, Logan EM, Cook GT, Pulford ID. Distributions, inventories and isotopic composition of lead in ${ }^{210} \mathrm{~Pb}$ dated peat cores from contrasting biogeochemical environments: Implications for lead mobility. Sci Total Environ 1998b;223:25-35.

Martínez-Cortizas A, Pontevedra-Pombal X, Nóvoa-Muñoz JC, García-Rodeja E. Four thousand years of atmospheric $\mathrm{Pb}$, $\mathrm{Cd}$ and $\mathrm{Zn}$ deposition recorded by the ombrotrophic paet 
bog of Penido Vello (North-Western Spain). Water Air Soil Poll 1997;100:387-403.

Martínez-Cortizas A, Garcia-Rodeja E, Pontevedra Pombal X, Nóvoa-Muñoz JC, Weiss D, Cherbulin A. Atmospheric Pb deposition in Spain during the last 4600 years recorded by two ombrotrophic peat bogs and implications for the use of peat as archive. Sci Total Environ 2002;292:33-44.

Mighall TM, Abrahams PW, Grattan JP, Hayes D, Timberlake S, Forsyth S. Geochemical evidence for atmospheric pollution derived from prehistoric copper mining at Copa Hill, Cwmystwyth, mid-Wales, UK. Sci Total Environ 2002;292: 69-80.

Monna F, Loizeau J-L, Thomas BA, Guéguen C, Favarger P$\mathrm{Y}$. $\mathrm{Pb}$ and $\mathrm{Sr}$ isotope measurements by inductively coupled plasma-mass spectrometer: efficient time management for precise improvement. Spectrochim Acta B 1998;59:13171333.

Monna F, Hamer K, Lévêque J, Sauer M. Pb isotopes as a reliable marker of early mining and smelting in the Northern Harz province (Lower Saxony, Germany). J Geochem Explor 2000a;68:201-210.

Monna F, Loizeau J-L, Thomas B, Guéguen C, Favarger P-Y, Losno R, Dominik J. Noise identification and sampling frequency determination for precise isotopic measurements by quadrupole-based inductively coupled plasma mass spectrometry. Analusis 2000b;28:750-757.

Monna F, Petit C, Guillaumet J-P, Jouffroy-Bapicot I, Blanchot C, Dominik J, Losno R, Richard H, Lévêque J, Château C. History and environmental impact of mining activity in Celtic aeduan territory recorded in a peat bog (Morvan, France). Environ Sci Technol 2004;38(3):657-673.

Moore PD, Evans AR, Chater M. In: Behre K-E, editor. Palynological and stratigraphic evidence for hydrological changes in mires associated with human activity, Anthropogenic indicators in pollen diagrams. Rotterdam: A.A. Balkema, 1986. p. 209-220.

Moris N. Composition of organic materials of peat soils in Peninsular Malaysia. In: Zauyah S, Wong CB, Paramanathan $\mathrm{S}$, editors. Recent developments in soil genesis and classification, Kuala Lumpur, Malaysia. Kaula Lumpur, MY: Malaysian Society of Soil Science, 1989. p. 81-87.

Munksgaards NC, Parry DL. Lead isotope ratios determined by ICP-MS: Monitoring of mining-derived metal particulates in atmospheric fallout, Northern Territory, Australia. Sci Total Environ 1998;217:113-125.

Norton SA, Evans GC, Kahl JS. Comparison of $\mathrm{Hg}$ and $\mathrm{Pb}$ fluxes to hummocks and hollows of ombrotrophic big heath bog and to nearby Sergeant Mt. pond, Maine, USA. Water Air Soil Poll 1997;100:271-286.

Nriagu JO. Lead and lead poisoning in antiquity. New York: Wiley, 1983.

Reille M, 1992. Pollen et spores d'Europe et d'Afrique du Nord. Ed. Laboratoire de botanique historique et palynologie. Marseille.

Renberg I, Brännvall M-J, Bindler R, Emteryd O. Atmospheric lead pollution history during four millenia (2000 BC to 2000 AD) in Sweden. Ambio 2000;29:150-156.
Renberg I, Bindler R, Brännvall M-L. Using the historical atmospheric lead-deposition record as a chronological marker in sediment deposits in Europe. Holocene 2001;11:511516.

Richard H, Eschenlhor L. Essai de correlation entre les données polliniques et les données archéologiques: le cas des forêts de Lajoux dans les Franches-Montagnes (Lajoux-Suisse). Rev. darchéométrie 1998;22:29-37.

Rosman KJR, Chisoholm W, Hong S, Candelone J-P, Boutron CF. Lead from Carthaginian and roman Spanish mines isotopically identified in Greenland ice dated from $600 \mathrm{BC}$ to 300 AD. Environ Sci Technol 1997;31:3413-3416.

Rovira S. 1998. Origin and diffusion of metallurgy in Spain: a review at the light of radiocarbone dates. Symposium C14 Archéologie, pp. 219-224.

Schettler G, Romer RL. Anthropogenic influences on $\mathrm{Pb} / \mathrm{Al}$ and lead isotopic signature in annually layered Holocene Maar lake sediments. Appl Geochem 1998;13(6):787-797.

Settle D, Patterson C. Lead in albacore: guide to lead pollutions in Americans. Science 1980;207:1167-1176.

Shotyk W. Peat bog archives of atmospheric metal deposition: geochemical evaluation of peat profiles, natural variations in metal concentrations, and metal enrichment factors. Environ Rev 1996a;4:149-183.

Shotyk W. Natural and anthropogenic enrichments of $\mathrm{As}, \mathrm{Cu}$, $\mathrm{Pb}, \mathrm{Sb}$, and $\mathrm{Zn}$ in ombrotrophic vs. minerotrophic peat bog profiles, Jura Mountains, Switzerland. Water Air Soil Poll 1996b;90:375-405.

Shotyk W, Weiss D, Appleby P, Cherbukin A, Frei R, Gloor M, Kramer J, Reese S, Van der Knaap W. History of atmospheric lead deposition since $12370{ }^{14} \mathrm{C}$ yr BP from a peat bog, Jura Mountains, Switzerland. Science 1998;281:1635-1640.

Shotyk W, Weiss D, Kramers JD, Frei R, Cherbukin AK, Gloor M, Reese S. Geochemistry of the peat bog at Etang de la Gruère, Jura Mountains, Switzerland, and its record of atmospheric $\mathrm{Pb}$ and lithogenic trace metals ( $\mathrm{Sc}, \mathrm{Ti}, \mathrm{Y}, \mathrm{Zr}$, and REE) since $12370{ }^{14} \mathrm{C}$ yr BP. Geochem Cosmochim Acta 2001;65(14):2337-2360.

Shotyk W. The chronology of anthropogenic, atmospheric $\mathrm{Pb}$ deposition recorded by peat cores in three minerogenic peat deposits from Switzerland. Sci Total Environ 2002;292:1931.

Shotyk W, Krachler M, Martinez-Cortizas A, Cheburkin AK, Emons H. A peat bog record of natural, pre-anthropogenic enrichments of trace elements in atmospheric aerosols since $12370{ }^{14} \mathrm{C}$ yr BP, and their variation with Holocene climate change Earth. Planet Sci Lett 2002a;199:21-37.

Shotyk W, Weiss D, Heisterkamp M, Cheburkin AK, Appleby PG, Adams FC. New peat bog record of atmospheric possultion in Switzerland: $\mathrm{Pb}$ concentrations, enrichment factors, isotopic composition, and organolead species. Environ Sci Technol 2002b;36:3893-3900.

Stos-Gale Z, Gale NH, Houghton J, Speakman R. Lead isotope data from the isotrace laboratory, Oxford: archaeometry data base 1, ores from Western Mediterranean. Archaeometry 1995;37(2):407-415. 
Stuiver M, Reimer PJ, Bard E, Beck JW, Burr GS, Hughen KA, Kromer B, McCormac FG, Plicht J, Spurk M. INTCAL98 radiocarbon age calibration 24 000-0 cal BP. Radiocarbon 1998;40:1041-1083.

Van Geel B, Bregman R, Van der Molen PC, Dupont LM, Van Driel-Murray C. Holocene raised bog deposits in the Netherlands as geochemical archives of prehistoric aerosols. Acta Bot Neerl 1989;38:467-476.

Vile MA, Wieder RK, Novàk M. Mobility of lead in Sphagnum-derived peat. Biogeochem. 1999;45:35-52.

Wedepohl KH. The composition of the crust. Geochim Cosmochim Acta 1995;59(7):1217-1232.

Weiss D, Shotyk W, Cherburkin AK, Gloor M, Reese S. Atmospheric lead deposition from 12400 to ca. 2000 yrs $\mathrm{BP}$ in a peat bog profile, Jura Mountians, Switzerland. Water Air Soil Poll 1997;100:311-324.

Weiss D, Shotyk W, Appleby PG, Kramers JD, Cheburkin $\mathrm{AK}$. Atmospheric $\mathrm{Pb}$ deposition since the Industrial Revolution recorded by five Swiss peat profiles: enrichment factors, fluxes, isotopic composition, and sources. Environ Sci Technol 1999;1999(33):1340-1352.
Weiss D, Shotyk W, Boyle EA, Kramers JD, Appleby PG, Cheburkin AK. Comparative study of the temporal evolution of atmospheric lead deposition in Scotland and Eastern Canada using blanket peat bogs. Sci Total Environ 2002;292:7-18.

West S, Charman DJ, Grattan JP, Cherburkin AK. Heavy metals on Holocene peats from South-West England: detecting mining impacts and atmospheric pollution. Water Air Soil Poll 1997;100:343-353.

Williams M. Dark ages and dark areas: global deforestation in the deep past. J Hist Geo 2000;26:28-46.

Wiltshire PEJ, Edwards KJ. In: Chambers FM, editor. Mesolithic, early neolithic, and later prehistoric impacts on vegetation at a riverine site in Derbyshire, England, climate change and human impact on the landscape. Chapman and Hall, 1993. p. 157-168.

Wüst RAJ, Bustin RM, Lavkulich LM. New classification systems for tropical organic-rich deposits based on studies of the Tasek Bera Basin, Malaysia. Catena 2003;751:1-31. 